\title{
Description of Pseudochrobactrum gen. nov., with the two species Pseudochrobactrum asaccharolyticum sp. nov. and Pseudochrobactrum saccharolyticum sp. nov.
}

\author{
Correspondence \\ Peter Kämpfer \\ peter.kaempfer@agrar. \\ uni-giessen.de
}

\author{
Peter Kämpfer, ${ }^{1}$ Ramon Rosselló-Mora, ${ }^{2}$ Holger C. Scholz, ${ }^{3}$ \\ Christina Welinder-Olsson, ${ }^{4}$ Enevold Falsen ${ }^{4}$ and Hans-Jürgen Busse ${ }^{5}$
${ }^{1}$ Institut für Angewandte Mikrobiologie, Justus-Liebig-Universität Giessen, Heinrich-Buff-Ring 26-32, D-35392 Giessen, Germany
${ }^{2}$ Institut Mediterrani d'Estudis Avancats (CSIC-UIB), E-07190 Esporles, Mallorca, Spain
${ }^{3}$ Bundeswehr Institute of Microbiology, D-80937 Munich, Germany
${ }^{4}$ Culture Collection University of Göteborg, Department of Clinical Bacteriology, S-41346
Göteborg, Sweden
${ }^{5}$ Institut für Bakteriologie, Mykologie und Hygiene, Veterinärmedizinische Universität, A-1210 Wien, Austria

Two Gram-negative, rod-shaped, oxidase-positive, non-spore-forming, non-motile bacteria (CCUG $46016^{\top}$ and CCUG $33852^{\top}$ ), isolated from a knee aspirate of a 66-year-old man and an industrial glue, respectively, were studied for their taxonomic position. On the basis of chemotaxonomic data [i.e. major ubiquinone (Q-10), major polar lipids (phosphatidylethanolamine, phosphatidylglycerol and phosphatidylcholine $)$ and major fatty acids $\left(\mathrm{C}_{18: 1} \omega 7 c\right.$ and $\mathrm{C}_{19: 0}$ cyclo $\omega 8 c)$ ] and $16 \mathrm{~S}$ rRNA gene sequence similarity, both strains belong to the Alphaproteobacteria. The presence of spermidine and putrescine as the predominant polyamines in CCUG $46016^{\top}$ were in agreement with its phylogenetic affiliation in the vicinity of the genus Ochrobactrum. 16S rRNA gene sequence similarities between both strains and established species within the genera Bartonella, Ochrobactrum and Brucella were less than $95 \%$. Although both organisms showed highest 16S rRNA gene sequence similarity to members of Brucella, phenotypic features (including chemotaxonomic features) were more like those of members of the genus Ochrobactrum. Sequence comparison of the $\operatorname{rec} A$ genes confirmed the separate phylogenetic position of the two strains. On the basis of DNA-DNA pairing results and physiological and biochemical data, the two strains can be clearly differentiated from each other and from all known Ochrobactrum species. It is evident that these organisms represent two novel species in a new genus, Pseudochrobactrum gen. nov., for which the names Pseudochrobactrum asaccharolyticum sp. nov. (the type species, type strain CCUG $46016^{\top}=$ CIP $108977^{\top}$ ) and Pseudochrobactrum saccharolyticum sp. nov. (type strain CCUG $33852^{\top}=$ CIP $108976^{\top}$ ) are proposed.
The genus Ochrobactrum was first described by Holmes et al. (1988). At present, the genus comprises five species:

\footnotetext{
Abbreviation: PME, phosphatidylmonomethylethanolamine.

The GenBank/EMBL/DDBJ accession numbers for the 16S rRNA gene sequences of strains CCUG $46016^{\top}$ and CCUG $33852^{\top}$ are $\mathrm{AM} 180485$ and $\mathrm{AM} 180484$, respectively, and those of the partial recA sequences of strains CCUG $46016^{\top}$ and CCUG $33852^{\top}$ are AM118081 and AM118082.

A multiple sequence alignment of partial $\operatorname{rec} A$ gene sequences and a two-dimensional TLC of the polar lipids of CCUG $46016^{\top}$ are available as supplementary material in IJSEM Online.
}

Ochrobactrum anthropi Holmes et al. 1988, Ochrobactrum intermedium Velasco et al. 1998, Ochrobactrum tritici Lebuhn et al. 2000, Ochrobactrum grignonense Lebuhn et al. 2000 and Ochrobactrum gallinifaecis Kämpfer et al. 2003. The status of 'Ochrobactrum lupini' (Trujillo et al., $2005)$ is not yet clear.

On the basis of 16S rRNA gene sequence data, members of the genus Brucella are most closely related to members of the genus Ochrobactrum; however, they clearly differ on the basis of serology, Western blot profiles and protein patterns (Velasco et al., 1998). An overview of the genus Brucella is 
provided by Moreno \& Moriyon (2001). Bacteria of the genus Bartonella are aerobic, fastidious, oxidase-negative, slow-growing organisms. Currently, 19 species are recognized, all of which are associated with mammalian hosts and can be differentiated on the basis of genetic analyses (Breitschwerdt \& Kordick, 2000; Bermond et al., 2002; Pitulle et al., 2002; Zeaiter et al., 2002). Based on 16S rRNA gene sequence comparisons, members of the genus Bartonella also fall into the Alphaproteobacteria, with species of Brucella, Rhizobium and Agrobacterium as closest relatives. In general, the genus Bartonella is relatively homogeneous, with members exhibiting greater than $95 \%$ similarity among aligned $16 \mathrm{~S}$ rRNA gene sequences.

Strain CCUG $46016^{\mathrm{T}}$ was isolated on blood agar at $37^{\circ} \mathrm{C}$ from a knee aspirate of a 66-year-old man in Uddevalla, Sweden. Strain CCUG $33852^{\mathrm{T}}$ was isolated on blood agar at $37^{\circ} \mathrm{C}$ from an industrial glue in Göteborg, Sweden. Both strains formed beige-coloured colonies on blood agar. Subcultivation was done on tryptone soy agar (TSA) at $28^{\circ} \mathrm{C}$ for $48 \mathrm{~h}$. On this agar, both organisms were able to grow at $15-45^{\circ} \mathrm{C}$, but not at 10 or $50^{\circ} \mathrm{C}$. Growth at $30^{\circ} \mathrm{C}$ was also observed on nutrient agar, MacConkey agar and R2A agar (all from Oxoid).

Gram-staining was performed as described by Gerhardt et al. (1994). Cell morphology was observed under a Zeiss light microscope at $\times 1000$, with cells grown for 3 days at $28^{\circ} \mathrm{C}$ on TSA. The $16 \mathrm{~S}$ rRNA gene was analysed as described by Kämpfer et al. (2003). Phylogenetic analysis was performed using the ARB (Strunk et al., 2000; Ludwig et al., 2004) and MEGA version 2.1 (Kumar et al., 2001) software packages after multiple alignment of data by CLUSTAL X (Thompson et al., 1997). The sequenced lengths of the $16 \mathrm{~S}$ rRNA genes of strains CCUG $46016^{\mathrm{T}}$ and CCUG $33852^{\mathrm{T}}$ were $1457 \mathrm{bp}$ and 1401 bp, respectively (GenBank accession nos AM180485 and AM180484, respectively). Nucleotide sequence similarities were below $95 \%$ with all species of the genera Bartonella (94.2 and $94 \cdot 3 \%$, respectively), Brucella $(94 \cdot 6-94 \cdot 8 \%)$ and Ochrobactrum $(93 \cdot 8-94 \cdot 6 \%)$ with validly described names. The phylogenetic tree shown in Fig. 1 results from a neighbour-joining reconstruction modified after comparison with maximum-parsimony and maximum-likelihood trees and with the use of different datasets as reported previously (Albert et al., 2005). The multifurcation shown in the tree represents branching orders that could not be resolved by the multiple reconstructions as recommended by Ludwig et al. (1998). In all calculations, both sequences appeared on a single phylogenetic branch, indicating their independent affiliation.

Partial recA sequences of some Ochrobactrum type strains and strains of Brucella species were amplified by PCR with primers recA-BrucOchro-f ( $5^{\prime}$-ATGTCTCAAAATTCATTGCGAC-3') and recA-BrucOchro-r (5'-AGCATCTTCTTCCGGTCCGC-3') to generate a 1065 bp fragment. Partial recA sequences (909 bp) of strains CCUG $46016^{\mathrm{T}}$ and CCUG $33852^{\mathrm{T}}$ were amplified by PCR with primers RecA-PsOchro-f (5'-AAGGCTCTGGACGCGGCACT-3')

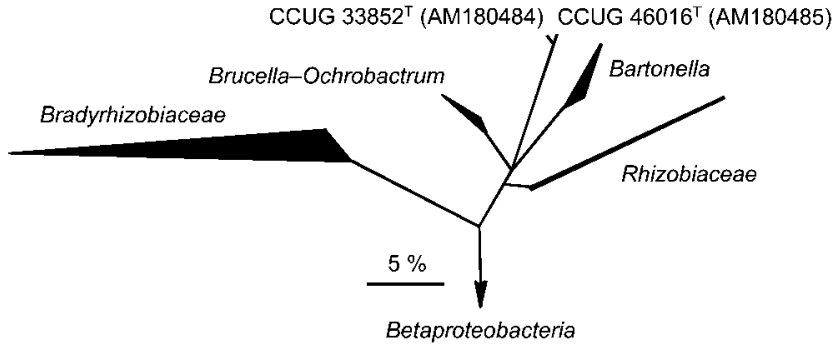

Fig. 1. $16 \mathrm{~S}$ rRNA gene sequence phylogenetic neighbour-joining tree reconstruction showing the affiliation of Pseudochrobactrum species to their closest relatives. The tree topology shows the consensus of neighbour-joining, maximum-parsimony and maximumlikelihood algorithms with different datasets, as implemented in the ARB software package (Ludwig et al., 2004). In cases where the branching order was irresolvable, a multifurcation was drawn (Ludwig et al., 1998). Bar, $5 \%$ sequence dissimilarity.

and RecA-PsOchro-r (5'-CGCAAGGTCAGTTCAATCTCAT- $\left.3^{\prime}\right)$.

Subsequent sequencing and sequence comparison analyses of the $\operatorname{rec} A$ genes revealed multiple sequence variations within $r e c A$ among the investigated strains (see the multiple sequence alignment available as Supplementary Fig. S1 in IJSEM Online). The similarity between $r e c A$ sequences of CCUG $46016^{\mathrm{T}}$ and CCUG $33852^{\mathrm{T}}$ was $91 \%$ over $909 \mathrm{nt}$. Lower similarity values were observed with species of Brucella $(80 \cdot 1-81 \cdot 0 \%)$, Ochrobactrum $(80 \cdot 7-81 \cdot 4 \%)$ and Bartonella $(76 \cdot 3 \%)$. CCUG $46016^{\mathrm{T}}$ and CCUG $33852^{\mathrm{T}}$ shared several motifs within $r e c A$ that were absent from sequences in species of Bartonella, Brucella and Ochrobactrum (Supplementary Fig. S1).

Strains CCUG $46016^{\mathrm{T}}$ and CCUG $33852^{\mathrm{T}}$ were found as separate branches in the phylogenetic tree of recA sequences (909 nt) (Fig. 2). The tree was constructed using the online accessible bioinformatics tools of HUSAR (available from http://genius.embnet.dkfz-heidelberg.de/menu/w2h/w2hdkfz) from CLUSTAL W using CLUSTREE neighbour-joining and the Kimura two-parameter model; 1000 bootstrap resamplings were performed. The tree was rooted using the sequence of Mesorhizobium loti MAFF 303099 as an outgroup.

Results of chemotaxonomic analyses are given in the genus description. The following compounds were analysed: respiratory quinones (Tindall, 1990; Altenburger et al., 1996), polyamines (Busse \& Auling, 1988; Busse et al., 1997), polar lipids (Ventosa et al., 1993) and fatty acids (Kämpfer \& Kroppenstedt, 1996). The presence of the quinone system ubiquinone Q-10 (97\%) supports affiliation of CCUG $46016^{\mathrm{T}}$ and CCUG $33852^{\mathrm{T}}$ to the Alphaproteobacteria, where the majority of species have Q-10 as the major quinone (Lechner et al., 1995; Yokota et al., 1992). In addition, CCUG $46016^{\mathrm{T}}$ contained small amounts of Q-9 (3\%). Strain CCUG $46016^{\mathrm{T}}$ contained the following polyamines [in $\mu \mathrm{mol}$ (g dry weight $)^{-1}$ ]: spermidine, 63.8; putrescine, 


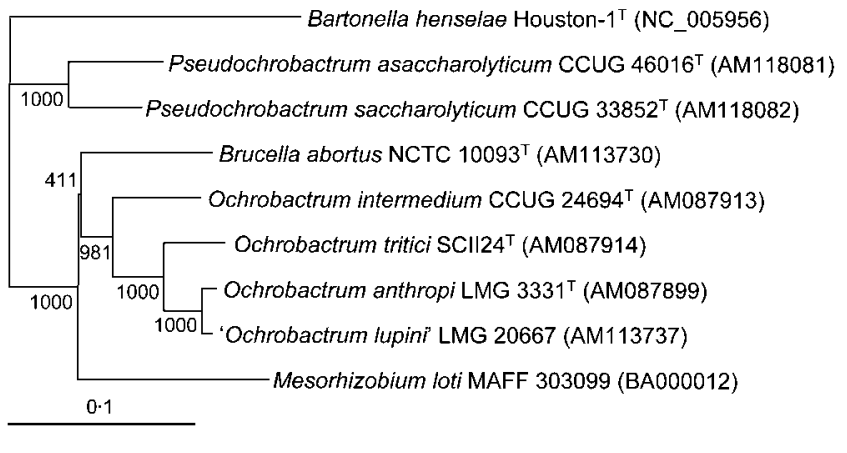

Fig. 2. Phylogenetic tree reconstruction with $\operatorname{rec} A$ sequences (909 nt) using CLUSTREE neighbour-joining analysis and the Kimura two-parameter model. Bar, $0 \cdot 1$ divergent residues per site. The significance of each branch is indicated by a bootstrap value from 1000 repetitions. The tree was rooted using the sequence of Mesorhizobium loti MAFF 303099 as an outgroup.

11.6; diaminopropane, $3 \cdot 8$; spermine, $0 \cdot 5$; and cadaverine, $0 \cdot 1$. This profile is similar to those reported for species of Ochrobactrum (Lechner et al., 1995; Hamana \& Takeuchi, 1998; Kämpfer et al., 2003), but distinct from the polyamine patterns of members of the genera Rhizobium, Mesorhizobium, Sinorhizobium, Aminobacter, Pseudaminobacter, Phyllobacterium and Mycoplana, which have been shown to contain sym-homospermidine in at least minor amounts (Busse \& Auling, 1988; Hamana \& Takeuchi, 1998; Kämpfer et al., 1999). The polar lipid profiles of CCUG $46016^{\mathrm{T}}$ (TLC available as Supplementary Fig. S2 in IJSEM Online) and CCUG $33852^{\mathrm{T}}$ (not shown) were almost identical and were similar to those of species of the related genera Aminobacter, Pseudaminobacter, Ochrobactrum (Kämpfer et al., 1999, 2003), Brucella (Thiele et al., 1971; H.-J. Busse, unpublished results), Sinorhizobium (Geiger et al., 1999) and Mesorhizobium (Choma \& Komaniecka, 2002). The absence of unknown aminolipid AL2 shown to be present in $O$. gallinifaecis Iso $196^{\mathrm{T}}$, O. anthropi LMG 7991 (Kämpfer et al., 2003), O. anthropi CCUG $24695^{\mathrm{T}}$ and O. intermedium LMG $3301^{\mathrm{T}}$ (B. Huber and H.-J. Busse, unpublished results) distinguishes CCUG $46016^{\mathrm{T}}$ and CCUG $33852^{\mathrm{T}}$ from Ochrobactrum species. Phosphatidyldimethylethanolamine shared almost identical chromatographic behaviour with the unknown aminolipid AL1. The existence of two lipids at almost the same position in the two-dimensional TLC (spot between phosphatidylglycerol and phosphatidylethanolamine; available as supplementary material in IJSEM Online) could be clearly identified when the plate was first sprayed with ninhydrin reagent and afterwards with molybdenum blue reagent. Only the lower part of the ninhydrin-positive spot stained blue with molybdenum blue reagent. Polar lipid profiles did not clearly distinguish CCUG $46016^{\mathrm{T}}$ and CCUG $33852^{\mathrm{T}}$ from two analysed Brucella strains (results not shown). However, the content of phosphatidylmonomethylethanolamine (PME) might be a distinguishing characteristic. In Brucella species, this lipid was not detectable or was present only in minor amounts, whereas it was a major compound in the polar lipid profiles of CCUG $46016^{\mathrm{T}}$ and CCUG $33852^{\mathrm{T}}$. However, the suitability of PME as a distinguishing trait would have to be substantiated by analysis of additional strains. Unfortunately, no information is available on polar lipids in Bartonella nor could strains of this genus be made available for our study. The fatty acid profiles of strains CCUG $46016^{\mathrm{T}}$ and CCUG $33852^{\mathrm{T}}$ (Table 1) revealed mainly $\mathrm{C}_{19: 0}$ cyclo $\omega 8 \mathrm{c}(7 \cdot 3-$ $14 \cdot 3 \%), \mathrm{C}_{18: 1} \omega 7 c(74 \cdot 6-74 \cdot 9 \%), \mathrm{C}_{16: 0}(1 \cdot 9-5 \cdot 6 \%)$ and $\mathrm{C}_{18: 0}(7 \cdot 4-10 \cdot 9 \%)$. The presence of $\mathrm{C}_{19: 0}$ cyclo $\omega 8 \mathrm{c}$ appears to be useful for differentiation of CCUG $46016^{\mathrm{T}}$ and CCUG $33852^{\mathrm{T}}$ from Brucella and Bartonella species. Whereas Brucella species were shown to contain this fatty acid either only in traces (Brucella canis; Dees et al., 1981) or as a predominant compound ( $>34 \%$ in the four other species; Dees et al., 1980; 1981; Coloe et al., 1984), it was completely absent in fatty acid profiles of Bartonella species (Welch et al., 1992; Regnery et al., 1992; Daly et al., 1993). However, this observation has to be considered with care because the data for Brucella and Bartonella species were obtained from biomass grown on blood-supplemented media.

Results of the physiological characterization are given in the species description and in Table 2. Methods used have been described previously (Kämpfer et al., 1991). Both organisms can be clearly differentiated on the basis of several tests. A comparison with the physiological profiles of Bartonella species is difficult. As pointed out by Breitschwerdt \& Kordick (2000), biochemical profiles of Bartonella species are fairly neutral. Members of the genus Brucella are biochemically quite heterogeneous.

The $\mathrm{G}+\mathrm{C}$ content for strain CCUG $46016^{\mathrm{T}}$ was determined as described by Ziemke et al. (1998). DNA-DNA hybridization experiments were performed with CCUG $46016^{\mathrm{T}}$ and type strains of all Ochrobactrum species using the method described by Ziemke et al. (1998), except that, for nick translation, $2 \mu \mathrm{g}$ DNA was labelled during a $3 \mathrm{~h}$ incubation at $15^{\circ} \mathrm{C}$. Strain CCUG $46016^{\mathrm{T}}$ showed relatively low DNADNA relatedness to O. anthropi LMG $3331^{\mathrm{T}}(46 \%)$, O. intermedium LMG $3301^{\mathrm{T}}(42 \%)$, O. tritici LMG $18957^{\mathrm{T}}$ (47\%), O. grignonense DSM $13338^{\mathrm{T}}(53 \%)$ and O. gallinifaecis Iso $196^{\mathrm{T}}(38 \%)$. DNA-DNA hybridization values between strains CCUG $46016^{\mathrm{T}}$ and CCUG $33852^{\mathrm{T}}$ were $41 \cdot 9 \%$. Pooled standard deviations of all hybridization experiments were between $3 \cdot 9$ and $7 \cdot 9 \%$.

From the results of $16 \mathrm{~S}$ rRNA gene and recA sequencing and from the physiological characteristics, it is evident that strains CCUG $46016^{\mathrm{T}}$ and CCUG $33852^{\mathrm{T}}$ differ from each other and from all species of the genera Bartonella, Brucella and Ochrobactrum. For this reason, a new genus with two novel species is proposed.

\section{Description of Pseudochrobactrum gen. nov.}

Pseudochrobactrum (Pseud.och.ro.bac'trum. Gr. adj. pseudes false; N.L. neut. n. Ochrobactrum a bacterial genus name; N.L. neut. n. Pseudochrobactrum false Ochrobactrum). 
Table 1. Major fatty acid composition (\%) of strains CCUG $46016^{\top}$ and CCUG $33852^{\top}$ and type strains of the genus Ochrobactrum

Strains: 1, CCUG $46016^{\mathrm{T}}$; 2, CCUG $33852^{\mathrm{T}}$; 3, O. gallinifaecis Iso $196^{\mathrm{T}}$; 4, O. intermedium LMG $3301^{\mathrm{T}}$; 5, O. anthropi LMG $3331^{\mathrm{T}}$; 6, O. grignonense DSM $13338^{\mathrm{T}}$; 7, O. tritici LMG $18957^{\mathrm{T}}$, 8, 'O. Iupini' LUP21 (data from Trujillo et al. 2005). All strains were grown on TSA at $28^{\circ} \mathrm{C}$ for $48 \mathrm{~h}$ prior to fatty acid analysis. For unsaturated fatty acids, the position of the double bond is located by counting from the methyl $(\omega)$ end of the carbon chain; cis and trans isomers are indicated by the suffixes $c$ and $t$, respectively. - , Not detected.

\begin{tabular}{|c|c|c|c|c|c|c|c|c|}
\hline Fatty acid & 1 & 2 & 3 & 4 & 5 & 6 & 7 & 8 \\
\hline \multicolumn{9}{|l|}{ Saturated } \\
\hline $\mathrm{C}_{12: 0}$ & - & $0 \cdot 7$ & - & - & - & - & - & - \\
\hline $\mathrm{C}_{14: 0}$ & - & - & $0 \cdot 7$ & - & - & - & - & - \\
\hline $\mathrm{C}_{16: 0}$ & $5 \cdot 5$ & $1 \cdot 9$ & $8 \cdot 9$ & $3 \cdot 7$ & $6 \cdot 6$ & $2 \cdot 9$ & $3 \cdot 7$ & $4 \cdot 2$ \\
\hline $\mathrm{C}_{17: 0}$ & & & & $3 \cdot 1$ & $1 \cdot 4$ & $1 \cdot 7$ & $0 \cdot 9$ & $1 \cdot 6$ \\
\hline $\mathrm{C}_{18: 0}$ & $11 \cdot 0$ & $7 \cdot 4$ & $3 \cdot 7$ & $4 \cdot 1$ & $8 \cdot 8$ & $7 \cdot 2$ & $9 \cdot 6$ & $3 \cdot 0$ \\
\hline \multicolumn{9}{|l|}{ Unsaturated } \\
\hline$C_{13: 1}$ at $12-13$ & - & - & - & - & $0 \cdot 6$ & $0 \cdot 7$ & - & - \\
\hline $\mathrm{C}_{17: 1} \omega 6 c$ & - & - & - & $1 \cdot 1$ & - & $0 \cdot 5$ & - & $1 \cdot 4$ \\
\hline $\mathrm{C}_{18: 1} \omega 7 c$ & $74 \cdot 9$ & $74 \cdot 6$ & $28 \cdot 8$ & $25 \cdot 8$ & $45 \cdot 6$ & $31 \cdot 6$ & $77 \cdot 9$ & $70 \cdot 8$ \\
\hline $\mathrm{C}_{18: 3} \omega 6 c(6,9,12)$ & - & $0 \cdot 5$ & - & - & - & - & - & - \\
\hline 11 -methyl- $\mathrm{C}_{18: 1} \omega 7 t$ & - & - & $1 \cdot 6$ & $1 \cdot 5$ & $1 \cdot 0$ & $1 \cdot 0$ & - & - \\
\hline $\mathrm{C}_{20: 1} \omega 7 c$ & - & - & - & - & - & $0 \cdot 8$ & - & - \\
\hline $\mathrm{C}_{20: 2} \omega 6,9 c$ & - & - & $1 \cdot 1$ & $0 \cdot 9$ & $0 \cdot 5$ & $0 \cdot 8$ & - & - \\
\hline \multicolumn{9}{|l|}{ Hydroxylated } \\
\hline $\mathrm{C}_{18: 1} 2-\mathrm{OH}$ & - & - & $1 \cdot 5$ & $1 \cdot 8$ & $0 \cdot 6$ & $0 \cdot 5$ & $1 \cdot 4$ & $6 \cdot 2$ \\
\hline $\mathrm{C}_{18: 0} 3-\mathrm{OH}$ & - & - & - & - & - & $0 \cdot 5$ & - & $1 \cdot 0$ \\
\hline Summed feature $3^{\star}$ & $0 \cdot 8$ & - & $3 \cdot 7$ & $0 \cdot 7$ & $1 \cdot 1$ & $1 \cdot 0$ & $0 \cdot 7$ & $2 \cdot 3$ \\
\hline \multicolumn{9}{|l|}{ Cyclopropane acids } \\
\hline $\mathrm{C}_{17: 0}$ cyclo & - & - & $2 \cdot 9$ & - & $0 \cdot 8$ & - & - & - \\
\hline $\mathrm{C}_{19: 0}$ cyclo $\omega 8 \mathrm{c}$ & $7 \cdot 3$ & $14 \cdot 3$ & $47 \cdot 2$ & $57 \cdot 4$ & $32 \cdot 7$ & $50 \cdot 2$ & $5 \cdot 9$ & $4 \cdot 3$ \\
\hline Unknown $13 \cdot 957 \dagger$ & - & - & - & - & - & $0 \cdot 2$ & - & - \\
\hline Unknown $14 \cdot 959 \dagger$ & $0 \cdot 6$ & $0 \cdot 9$ & - & - & $0 \cdot 3$ & $0 \cdot 7$ & - & - \\
\hline
\end{tabular}

*Summed features are groups of two or three fatty acids that cannot be separated by GLC with the MIDI system. Summed feature 3 contains $\mathrm{C}_{16: 1} \omega 7 c$ and/or $\mathrm{C}_{15: 0}$ iso 2-OH.

$\dagger$ Unknown fatty acids have no name listed in the peak library file of the MIDI system and therefore cannot be identified; they are referred to by their equivalent chain length.

Cells are non-motile, non-spore-forming rods (approx. $2 \mu \mathrm{m}$ in length). Gram-negative and oxidase-positive, showing an oxidative metabolism. The quinone system consists mainly of Q-10. Polyamine patterns comprise spermidine and putrescine as major compounds and 1,3-diaminopropane and spermine in minor amounts. Predominant polar lipids are phosphatidylethanolamine, phosphatidylmonomethylethanolamine, phosphatidylglycerol, diphosphatidylglycerol and phosphatidylcholine. Additionally, moderate amounts of phosphatidyldimethylethanolamine and unknown aminolipid AL1 and small amounts of unknown phospholipid PL1 and five unknown lipids (L1-L5) are detected. Fatty acid profiles contain large amounts of $\mathrm{C}_{18: 1} \omega 7 c$ and moderate amounts of $\mathrm{C}_{18: 0}$ and $\mathrm{C}_{19: 0}$ cyclo $\omega 8 \mathrm{c}$. Negative for a Brucella abortus- and Brucella melitensis-specific antigen (according to the assay of Baily et al., 1992). In $\operatorname{rec} A$ sequence analyses, most closely related to species of Brucella (80\%) and Ochrobactrum (81\%), followed by Bartonella (76\%). Species of the genus can be differentiated from Bartonella species by a positive oxidase reaction, non-fastidious growth and utilization of several organic acids (Table 2). The type species is Pseudochrobactrum asaccharolyticum.

\section{Description of Pseudochrobactrum asaccharolyticum sp. nov.}

Pseudochrobactrum asaccharolyticum (a.sac.cha.ro.ly'ti.cum. Gr. pref. a not; Gr. n. saccharon sugar; N.L. neut. adj. lyticum able to lyse from Gr. adj. lutikos able to loose; N.L. neut. adj. asaccharolyticum not digesting sugar).

Shares all characteristics listed in the genus description. Good growth occurs on R2A agar, TSA, nutrient agar and 
Table 2. Physiological characteristics of strains CCUG $46016^{\top}$ and CCUG $33852^{\top}$ and type strains of the genus Ochrobactrum

Strains: 1, CCUG 46016 ; 2, CCUG $33853^{\mathrm{T}}$; 3, O. gallinifaecis Iso $196^{\mathrm{T}} ; 4$, O. intermedium LMG $3301^{\mathrm{T}}$; 5, O. anthropi LMG $3331^{\mathrm{T}}$; 6 , O. grignonense DSM $13338^{\mathrm{T}} ; 7$, O. tritici LMG $18957^{\mathrm{T}}$. +, Positive; -, negative; $(+)$, weakly positive; pNA, para-nitroanilide; pNP, paranitrophenyl. All strains were positive for hydrolysis of L-alanine $p \mathrm{NA}$ and weak hydrolysis of bis- $p$ NP phosphate. All strains were negative for hydrolysis of aesculin, $p \mathrm{NP} \quad \beta$-D-galactopyranoside, $p \mathrm{NP} \quad \beta$-D-glucuronide, $p \mathrm{NP} \alpha$-D-glucopyranoside, $p \mathrm{NP} \quad \beta$-D-glucopyranoside, $p \mathrm{NP}$ phosphorylcholine and 2-deoxythymidine- $5^{\prime}-p \mathrm{NP}$ phosphate. All strains were also positive for assimilation of acetate, oxoglutarate, L-alanine, L-proline and L-serine. All strains were negative for assimilation of p-arbutin, salicin, putrescine, L-phenylalanine, L-tryptophan, 3-hydroxybenzoate, adipate, itaconate, mesaconate, phenylacetate, $\alpha$-D-melibiose and azelate. Hydrolysis of aesculin and $p$ NP $\beta$-D-galactopyranoside and assimilation of oxoglutarate, L-serine, phenylacetate and $\alpha$-D-melibiose were also tested using a different method by Holmes et al. (1988) with O. anthropi; results were in agreement with those of this study. Adipate assimilation was also tested using a different method by Velasco et al. (1998) with O. intermedium; results were in agreement with those of this study.

\begin{tabular}{|c|c|c|c|c|c|c|c|}
\hline Test & 1 & 2 & 3 & 4 & 5 & 6 & 7 \\
\hline \multicolumn{8}{|l|}{ Hydrolysis of: } \\
\hline pNP phenylphosphonate & - & - & - & - & - & - & $(+)$ \\
\hline L-Proline $p \mathrm{NA}^{a_{\star}}$ & + & + & + & $(+)$ & + & + & $(+)$ \\
\hline \multicolumn{8}{|l|}{ Assimilation of: } \\
\hline D-Fructose & - & + & - & + & + & + & + \\
\hline DL-3-Hydroxybutyrate ${ }^{b}$ & - & + & - & + & + & + & + \\
\hline D-Galactose ${ }^{b}$ & - & + & + & + & + & + & + \\
\hline $\begin{array}{l}\text { D-Ribose }{ }^{b}, \text { propionate }^{b} \text {, fumarate }{ }^{b} \text {, glutarate, } \\
\text { DL-lactate, L-malate }{ }^{b}, \text { pyruvate }^{b} \text {, ornithine }{ }^{b}\end{array}$ & - & + & + & + & + & + & + \\
\hline D-Maltose ${ }^{b c}$, adonitol $^{a b}$ & - & - & - & + & + & - & + \\
\hline$N$-Acetyl-D-glucosamine ${ }^{b}$ & - & + & - & + & + & - & + \\
\hline Sucrose ${ }^{b c}$ & - & - & - & - & + & - & + \\
\hline D-Trehalose & - & + & - & - & + & - & + \\
\hline Maltitol & - & - & - & - & + & - & - \\
\hline D-Mannitol & - & - & - & - & + & + & + \\
\hline trans-Aconitate ${ }^{b}$ & - & - & - & $(+)$ & - & - & - \\
\hline D-Cellobiose ${ }^{a b}$ & - & - & - & + & + & - & - \\
\hline$N$-Acetyl-D-galactosamine & - & - & - & + & $(+)$ & + & + \\
\hline Suberate $^{b}$ & - & - & - & - & - & - & + \\
\hline L-Aspartate ${ }^{b}$ & - & + & + & + & + & + & - \\
\hline
\end{tabular}

${ }^{*}$ Tested using a different method in another study for the type strains of the species listed; results were in agreement with those of this study. $a$, Lebuhn et al. (2000) with O. grignonense, O. intermedium, O. tritici and O. anthropi; b, Holmes et al. (1988) with O. anthropi; $c$, Velasco et al. (1998) with O. intermedium.

MacConkey agar at $25-30^{\circ} \mathrm{C}$. Beige, translucent and shiny colonies with entire edges form within $24 \mathrm{~h}$ on blood agar, with a diameter of approximately $2 \mathrm{~mm}$. Carbon source utilization (none of the sugars were utilized) and hydrolysis of chromogenic substrates (including differentiating characters for all Ochrobactrum species) are indicated in Table 2.

Type strain is CCUG $46016^{\mathrm{T}}\left(=\mathrm{CIP} 108977^{\mathrm{T}}\right)$, isolated from a knee aspirate of a 66-year-old man. The $\mathrm{G}+\mathrm{C}$ content of strain CCUG $46016^{\mathrm{T}}$ is $50 \cdot 9 \mathrm{~mol} \%$.

\section{Description of Pseudochrobactrum saccharolyticum sp. nov.}

Pseudochrobactrum saccharolyticum (sac.cha.ro.ly'ti.cum. Gr. n. saccharon sugar; N.L. neut. adj. lyticum able to lyse 
from Gr. adj. lutikos able to loose; N.L. neut. adj. saccharolyticum digesting sugar).

Good growth occurs on R2A agar, TSA, nutrient agar and MacConkey agar at $25-30^{\circ} \mathrm{C}$. Beige, translucent and shiny colonies with entire edges form within $24 \mathrm{~h}$ on blood agar, with a diameter of approximately $2 \mathrm{~mm}$. Carbon source utilization (several sugars were utilized) and hydrolysis of chromogenic substrates (including differentiating characters for all Ochrobactrum species) are indicated in Table 2.

The type strain is CCUG $33852^{\mathrm{T}}\left(=\mathrm{CIP} 108976^{\mathrm{T}}\right)$, isolated from an industrial glue.

\section{References}

Albert, R., Archambault, J., Rosselló-Mora, R., Tindall, B. \& Matheny, M. (2005). Bacillus acidicola sp. nov., a novel mesophilic, acidophilic species isolated from acidic Sphagnum peat bogs in Wisconsin. Int J Syst Evol Microbiol 55, 2125-2130.

Altenburger, P., Kämpfer, P., Makristathis, A., Lubitz, W. \& Busse, H.-J. (1996). Classification of bacteria isolated from a medieval wall painting. J Biotechnol 47, 39-52.

Baily, G. G., Krahn, J. B., Drasar, B. S. \& Stoker, N. G. (1992). Detection of Brucella melitensis and Brucella abortus by DNA amplification. J Trop Med Hyg 95, 271-275.

Bermond, D., Boulouis, H.-J., Heller, R., Van Laere, G., Monteil, H., Chomel, B. B., Sander, A., Dehio, C. \& Piémont, Y. (2002). Bartonella bovis Bermond et al. sp. nov. and Bartonella capreoli sp. nov., isolated from European ruminants. Int J Syst Evol Microbiol 52, 383-390.

Breitschwerdt, E. B. \& Kordick, D. L. (2000). Bartonella infection in animals: carriership, reservoir potential, pathogenicity, and zoonotic potential for human infection. Clin Microbiol Rev 13, 428-438.

Busse, H.-J. \& Auling, G. (1988). Polyamine pattern as a chemotaxonomic marker within the Proteobacteria. Syst Appl Microbiol 11, 1-8. Busse, H.-J., Bunka, S., Hensel, A. \& Lubitz, W. (1997). Discrimination of members of the family Pasteurellaceae based on polyamine patterns. Int J Syst Bacteriol 47, 698-708.

Choma, A. \& Komaniecka, I. (2002). Analysis of phospholipids and ornithine-containing lipids from Mesorhizobium spp. Syst Appl Microbiol 25, 326-331.

Coloe, P. J., Sinclair, A. J., Slattery, J. F. \& Burke, D. (1984). Differentiation of Brucella ovis from Brucella abortus by gas-liquid chromatographic analysis of cellular fatty acids. J Clin Microbiol 19, 896-898.

Daly, J. S., Worthington, M. G., Brenner, D. J. \& 7 other authors (1993). Rochalimaea elizabethae sp. nov. isolated from a patient with endocarditis. J Clin Microbiol 31, 872-881.

Dees, S., Thanabalasundrum, S., Moss, C. W., Hollis, D. G. \& Weaver, R. E. (1980). Cellular fatty acid composition of group IVe, a nonsaccharolytic organism from clinical sources. J Clin Microbiol 11, 664-668.

Dees, S. B., Hollis, D. G., Weaver, R. E. \& Moss, C. W. (1981). Cellular fatty acids of Brucella canis and Brucella suis. J Clin Microbiol 14, 111-112.

Geiger, O., Röhrs, V., Weissenmayer, B., Finan, T. M. \& ThomasOates, J. E. (1999). The regulator gene phoB mediates phosphate stress-controlled synthesis of the membrane lipid diacylglyceryl$\mathrm{N}, \mathrm{N}, \mathrm{N}$-trimethylhomoserine in Rhizobium (Sinorhizobium) meliloti. Mol Microbiol 32, 63-73.
Gerhardt, P., Murray, R. G. E., Wood, W. A. \& Krieg, N. R. (editors) (1994). Methods for General and Molecular Bacteriology. Washington, DC: American Society for Microbiology.

Hamana, K. \& Takeuchi, M. (1998). Polyamine profiles as chemotaxonomic markers within alpha, beta, gamma, delta, and epsilon subclasses of class Proteobacteria: distribution of 2-hydroxyputrescine and homospermidine. Microbiol Cult Coll 14, 1-14.

Holmes, B., Popoff, M., Kiredjian, M. \& Kersters, K. (1988). Ochrobactrum anthropi gen. nov., sp. nov. from human clinical specimens and previously known as group Vd. Int J Syst Bacteriol 38, 406-416.

Kämpfer, P. \& Kroppenstedt, R. M. (1996). Numerical analysis of fatty acid patterns of coryneform bacteria and related taxa. Can J Microbiol 42, 989-1005.

Kämpfer, P., Steiof, M. \& Dott, W. (1991). Microbiological characterization of a fuel oil contaminated site including numerical identification of heterotroph water and soil bacteria. Microb Ecol 21, 227-251.

Kämpfer, P., Müller, C., Mau, M., Neef, A., Auling, G., Busse, H.-J., Osborn, A. M. \& Stolz, A. (1999). Description of Pseudaminobacter gen. nov. with two new species, Pseudaminobacter salicylatoxidans sp. nov. and Pseudaminobacter defluvii sp. nov. Int J Syst Bacteriol 49, 887-897.

Kämpfer, P., Buczolits, S., Albrecht, A., Busse, H.-J. \& Stackebrandt, E. (2003). Towards a standardized format for the description of a novel species (of an established genus): Ochrobactrum gallinifaecis sp. nov. Int J Syst Evol Microbiol 53, 893-896.

Kumar, S., Tamura, K., Jakobsen, I.-B. \& Nei, M. (2001). MEGA2: molecular evolutionary genetics analysis software. Bioinformatics 17, $1244-1245$.

Lebuhn, M., Achouak, W., Schloter, M., Berge, O., Meier, H., Barakat, M., Hartmann, A. \& Heulin, T. (2000). Taxonomic characterization of Ochrobactrum sp. isolates from soil samples and wheat roots, and description of Ochrobactrum tritici sp. nov. and Ochrobactrum grignonense sp. nov. Int J Syst Evol Microbiol 50, 2207-2223.

Lechner, U., Baumbach, R., Becker, D., Kitunen, V., Auling, G. \& Salkinoja-Salonen, M. (1995). Degradation of 4-chloro-2-methylphenol by an activated sludge isolate and its taxonomic description. Biodegradation 6, 83-92.

Ludwig, W., Strunk, O., Klugbauer, S., Klugbauer, N., Weizenegger, N., Neumaier, J., Bachleitner, M. \& Schleifer, K.-H. (1998). Bacterial phylogeny based on comparative sequence analysis. Electrophoresis 19, 554-568.

Ludwig, W., Strunk, O., Westram, R. \& 29 other authors (2004). ARB: a software environment for sequence data. Nucleic Acids Res 32, 1363-1371.

Moreno, E. \& Moriyon, I. (2001). The genus Brucella. In The Prokaryotes: an Evolving Electronic Resource for the Microbiological Community, release 3.7. Edited by M. Dworkin and others. New York: Springer. http://141.150.157.117:8080/prokPUB/index.htm

Pitulle, C., Strehse, C., Brown, J. W. \& Breitschwerdt, E. B. (2002). Investigation of the phylogenetic relationships within the genus Bartonella based on comparative sequence analysis of the $r m p B$ gene, $16 \mathrm{~S}$ rDNA and 23S rDNA. Int J Syst Evol Microbiol 52, 2075-2080.

Regnery, R. L., Anderson, B. E., Clarridge, J. E., III, RodriguezBarradas, M. C., Jones, D. C. \& Carr, J. H. (1992). Characterization of a novel Rochalimaea species, $R$. henselae sp. nov., isolated from blood of a febrile, human immunodeficiency virus-positive patient. J Clin Microbiol 30, 265-274.

Strunk, O., Gross, O., Reichel, B. \& 10 other authors (2000). ARB: a software environment for sequence data. Department of Microbiology, Technische Universität München, Munich, Germany. http:// www.arb-home.de 
Thiele, O. W., Busse, D. \& Schwinn, G. (1971). Phosphatide der Brucellen. $Z$ Allg Mikrobiol 11, 249-254 (in German).

Thompson, J. D., Gibson, T. J., Plewniak, F., Jeanmougin, F. \& Higgins, D. G. (1997). The CLUSTAL_X windows interface: flexible strategies for multiple sequence alignment aided by quality analysis tools. Nucleic Acids Res 25, 4876-4882.

Tindall, B. J. (1990). A comparative study of the lipid composition of Halobacterium saccharovorum from various sources. Syst Appl Microbiol 13, 128-130.

Trujillo, M. E., Willems, A., Abril, A., Planchuelo, A.-M., Rivas, R., Ludena, D., Mateos, P. F., Martínez-Molina, E. \& Velázquez, E. (2005). Nodulation of Lupinus albus by strains of Ochrobactrum lupini sp. nov. Appl Environ Microbiol 71, 1318-1327.

Velasco, J., Romero, C., López-Goñi, I., Leiva, J., Díaz, R. \& Moriyón, I. (1998). Evaluation of the relatedness of Brucella spp. and Ochrobactrum anthropi and description of Ochrobactrum intermedium sp. nov., a new species with a closer relationship to Brucella spp. Int J Syst Bacteriol 48, 759-768.
Ventosa, A., Marquez, M. C., Kocur, M. \& Tindall, B. J. (1993). Comparative study of 'Micrococcus sp.' strains CCM 168 and CCM 1405 and members of the genus Salinicoccus. Int J Syst Bacteriol 43, 245-248.

Welch, D. F., Pickett, D. A., Slater, L. N., Steigerwalt, A. G. \& Brenner, D. J. (1992). Rochalimaea henselae sp. nov., a cause of septicemia, bacillary angiomatosis, and parenchymal bacillary peliosis. J Clin Microbiol 30, 275-280.

Yokota, A., Akagawa-Matsushita, M., Hiraishi, A., Katayama, Y., Urakami, T. \& Yamasato, K. (1992). Distribution of quinone systems in microorganisms: Gram-negative eubacteria. Bull Jpn Fed Cult Coll 8, 136-171.

Zeaiter, Z., Fournier, P.-E., Ogata, H. \& Raoult, D. (2002). Phylogenetic classification of Bartonella species by comparing groEL sequences. Int J Syst Evol Microbiol 52, 165-171.

Ziemke, F., Höfle, M. G., Lalucat, J. \& Rosselló-Mora, R. (1998). Reclassification of Shewanella putrefaciens Owen's genomic group II as Shewanella baltica sp. nov. Int J Syst Bacteriol 48, 179-186. 